\section{Mortalitet hos kreftpasienter}

En kombinasjon av profylaktisk antibiotikabehandling, luftkvalitetskontroll og barrierer mot infeksjon (som hansker og masker) reduserer risikoen for død hos kreftpasienter med høy risiko som får kjemoterapi (Lancet Infect Dis 2008, doi: 10.1016/ S1473-3099(08)70284-6).

En systematisk oversiktsartikkel viser at denne reduksjonen er på $40 \% 30$ dager etter behandling hos pasienter med akutt leukemi og hos dem som har gjennomgått stamcelletransplantasjon. Tre år senere var det fortsatt $14 \%$ redusert mortalitet.

Uten antibiotikaprofylakse ble effekten sterkt redusert, men forfatterne mener at luftkvalitetskontroll og bruk av barrierer også er viktig.

\section{Psoriasis og hyperleptinemi}

Forfatterne av en studie publisert i Archives of Dermatology konkluderer med at det er en sammenheng mellom psoriasis og hyperleptinemi, som kan medvirke til metabolsk syndrom (2008; 144: 1571-5).

77 pasienter med psoriasis ble sammenliknet med 81 kontrollpersoner. Det var signifikant flere av psoriasispasientene som var fete (OR 2,7) og hadde hypertensjon (OR 2,2) enn tilsvarende i kontrollgruppen.

Høye serum-leptinnivåer ble funnet hos kvinnelige deltakere $(0 R 6,1)$, fete deltakere (OR 3,5) og hos deltakere med hypertensjon (OR 2,2), metabolsk syndrom (OR $3,6)$ og psoriasis (OR 2,3). Sammenhengen mellom hyperleptinemi og psoriasis var uavhengig av kjønn og vekt.

\section{Snorking, søvnighet og nesetetthet}

Nesetetthet er assosiert med snorking og søvnighet på dagtid, med og uten allergisk rhinitt. Allergisk rhinitt uten nesetetthet er ikke assosiert med snorking eller tretthet om dagen.

Det er konklusjonen i en prospektiv spørreundersøkelse fra Japan (Arch Otolaryngol Head Neck Surg 2008; 134: 1254-7).

Hos pasienter med nesetetthet og allergisk rhinitt og pasienter med kun nesetetthet var det større sannsynlighet for snorking eller tretthet. For dem med allergisk rhinitt uten nesetetthet var det ikke signifikant større sannsynlighet enn i kontrollgruppen for snorking eller tretthet.

\title{
Upresis utvelgelse av hardt skadede
}

Påvisning av alvorlig skade i felten er viktig for å sikre riktig beredskapsnivå ved ankomst sykehus. En norsk stu-

die viser at pasientutvelgelsen

i prehospitalfasen er utilfredsstillende.

Vi brukte traumeregisterdata og analyserte presisjonsnivået ved triage (vurdering, behandling og prioritering av skadede) av traumepasienter innlagt ved Ullevål universitetssykehus (1). «Overtriage» ble definert som der mindre skadede likevel ble møtt av traumeteam, «undertriage» der alvorlig skadede ikke ble møtt av traumeteam.

Studien omfattet 4659 pasienter, hvorav $2221(48 \%)$ var alvorlig skadet. Traumeteamet ble varslet 4440 ganger, men bare 2002 ganger var pasienten alvorlig skadet, dvs. en overtriage på $55 \%$ og en undertriage på $10 \%$.

Skademekanikk ble brukt som eneste kriterium for traumeteamaktivering hos 1508 pasienter, hvorav kun 392 var alvorlig skadet (overtriage $78 \%$ ). For pasienter som

\section{Et SKUP for brukerne}

\section{Alt laboratorieutstyr som brukes i primærhelsetjenesten, bør være utprøvd av en nøytral instans som for eksempel det skandinaviske SKUP- initiativet.}

Skandinavisk Utprøving av laboratorieutstyr for Primærhelsetjenesten, SKUP, ble startet i 1997. Dette er et faglig samarbeid mellom Danmark, Sverige og Norge. I Norge er SKUP lagt til NOKLUS (Norsk kvalitetsforbedring av laboratorievirksomhet utenfor sykehus). SKUPs mål er å forbedre kvaliteten på pasientnær analysering i Skandinavia ved å fremskaffe objektiv og leverandøruavhengig informasjon om laboratorieutstyrets analytiske kvalitet og brukervennlighet. Vi har nylig publisert en artikkel om SKUPs virksomhet (1).

SKUP tilbyr leverandørene utprøvninger etter standardiserte protokoller. Laboratorieutstyret testes under optimale forhold av erfarne bioingeniører og på det stedet utstyret skal brukes - enten på legekontorer eller blant pasienter. En preevaluering gir nyttig informasjon til leverandører som skal ta en avgjørelse om de vil lansere nytt utstyr. Resultatene fra utprøvningene blir offentliggjort dersom utstyret markedsføres kom i følge med anestesilege, var utvelgelsen presis ( $35 \%$ overtriage, $2 \%$ undertriage), mens den var upresis for dem som kom med ambulanse (66\% overtriage, $17 \%$ undertriage). Alvorlig skadede som ikke ble mottatt av traumeteamet hadde en oddsratio for død etter 30 dager på 2,3 ( $<<0,001)$.

Høy overtriage er et ressursproblem, mens det er bekymringsfullt at $10 \%$ av de alvorlig skadede ikke ble møtt av traumeteamet. Funnene må tolkes varsomt, da det må antas at anestesilegebemannet utrykningstjeneste og ordinær ambulansetjeneste håndterer ulike pasientgrupper. Vi håper studien kan bidra til en debatt rundt hvordan triagepresisjonen kan økes, særlig siden fravær av traumeteam til alvorlig skadede påvirker pasientsikkerheten.

\section{Andreas J. Krüger}

andreas.kruger@snla.no

Stiftelsen Norsk Luftambulanse

\section{Litteratur}

1. Rehn M, Eken T, Krüger AJ et al. Precision of field triage in patients brought to a trauma centre after introducing trauma team activation guidelines. Scand J Trauma Resusc Emerg Med 2009; 17: 1 www.sjtrem.com/content/17/1/1 (17.1.2009). i Skandinavia. SKUP publiserer utprøvningsrapportene på www.skup.nu.

SKUP har utført over 70 utprøvninger av laboratorieutstyr beregnet for primærhelsetjenesten. Dette utgjør mer enn halvparten av det laboratorieutstyret som brukes i laboratorier utenfor sykehus i Skandinavia. Sju utprøvninger er stoppet pga. dårlig analysekvalitet og fem er fremdeles konfidensielle fordi instrumentene ikke er lansert i de skandinaviske land. SKUP bidrar dermed til at uegnet utstyr ikke blir markedsført i Skandinavia.

Bruk av SKUP-utprøvd utstyr eller utstyr evaluert av en tilsvarende nøytral instans burde vært et krav for å få refusjon. Utprøvningene burde vært fullt finansiert av offentlige helsemyndigheter eller av instrumentleverandørene. Ettersom det ikke er slik i dag, er det instrumentleverandørene som bestemmer hvilket utstyr som skal evalueres.

\section{Grete Monsen}

grete.monsen@noklus.no

SKUP i Norge

\footnotetext{
Litteratur

1. Sandberg S, Nordin G Mårtensson A et al. Laboratorieutrustning för primärvården bör utprövas av oberoende organ. Skandinaviska SKUP ett bra
} alternativ. Läkartidningen 2008: 105: 3334-9. 